\title{
The Mediating Role of Normative Commitment and the Moderating Role of Organisational Justice on the Influence of Career Development on Job Engagement
}

\author{
Mustafa Bekmezci ${ }^{1 *}$, Kenan Orçanlı1, Zafer Mehmet Fırat² \\ 1 Department of Business, Faculty of Economics, Administrative and Social Sciences, Toros University, 33000 Mersin, 45 Houses \\ Campus, Turkey \\ 2 Department of Business, Faculty of Land Military Academy, National Defence University, 06420 Ankara, Çankaya, Turkish \\ Military Academy Street, Turkey \\ * Corresponding author, e-mail: mustafa.bekmezci@toros.edu.tr
}

Received: 11 June 2020, Accepted: 03 August 2021, Published online: 28 January 2022

\begin{abstract}
An organisation's efficiency and effectiveness can be viewed as depending on the qualification of its employees. Organisational support and career development are among the factors that enable organisations to employ and retain qualified people. This study, which was conducted within the context of a social exchange, investigates the effect of career development on job engagement. As a result of the literature research, it has been determined that career development has a positive effect on job engagement, and it is further considered that normative commitment might have a mediating effect and organisational justice might have a moderating role in this relationship. The data was collected from 234 academics from four foundation universities in the Ankara and Mersin provinces of Turkey. The collected data were analysed using SPSS and AMOS package programs and the R and Python programming languages. The analyses demonstrate that there is a positive causal relationship between career development and job engagement, while normative commitment has a partial mediating role in this relationship, and organisational justice does not have a moderator role.
\end{abstract}

Keywords

career development, job engagement, normative commitment, organisational justice

\section{Introduction}

Everything changes rapidly in today's world, and this has led to a transformation in the human-organisation relationship. Although having people directing their energy and attention to their work can be viewed as a desirable behaviour, people's engagement with their jobs has decreased compared with the past; moreover, changing jobs for the sake of one's career has become accepted as normal. An individual has a positive attitude toward a particular behaviour (believes it) when he knows his behaviour is accompanied by potential outcomes. When the individual believes that he can achieve a better position and the mental work pressure will be decreased, he more likely leaves his work (Rasouli et al., 2014). In response to this situation, a significant amount of an organisation's energy is put into the attention that is given to employees. By relying on their human resources inside the organisation, organisations can improve their activities as much as possible. The human workforce may be considered the most valuable asset of an organisation and different factors affect its performance and efficiency (Hitka et al., 2017). Consequently, career development has been considered as a means of ensuring job engagement. Social exchange theory suggests that if an organisation provides economic and social benefits to its employee, the employee will also exhibit a positive attitude and behaviour toward the organisation. The key to retaining qualified people, to ensure that they strive for the benefit of the organisation and embrace the goals and values of the organisation, is to offer social and economic benefits to the employees. As a result of the literature review, it has been seen that there is a positive and significant relationship among normative commitment and organisational justice and the employees' job engagement, and normative commitment has a mediating role between career development and job engagement (Lu et al., 2013; Zhou et al., 2015; 
Weng and $\mathrm{Xi}, 2011)$. Organisational justice has a moderating role influencing attitudes, behaviours, and outcome variables; in other words, it can determine the conditions under which the relationship between the variables may change. Therefore, the mediating role of normative commitment and the moderating role of organisational justice on the effect of career development on job engagement have been investigated here.

\subsection{Career development and job engagement}

A career is generally considered as the progress one makes in one's professional life and a collection of experiences gained throughout this journey. Therefore, a career is work-related and lifelong (Cummings and Worley, 2009). Career development is defined as programmes, actions, and activities that are performed in order to ensure that employees achieve their career goals (Kılıç and Öztürk, 2010), and it represents a combination of the career planning efforts of the employee and the career management activities of the organisation (Büyükyaprak, 2015). Career development has several purposes including decreasing inefficiency; facilitating embracing goals; improving physiological satisfaction, motivation, and the organisational commitment of the employees; creating an organisational environment that appeals to the development, competence, and flexibility requests of the employees; and informing the employees about career processes and paths (Can, 1994). In that sense, career development includes activities that would help the employees reach their goals, such as improving skills, providing performance feedback to the employee, coaching, or mentoring, and assigning demanding tasks to the employee (Cummings and Worley, 2009).

Engagement deliberately directs an individual's energy, knowledge, and skills toward a certain goal (Koçel, 2014). Job engagement is an individual's physical dedication to work alone or with others; being mentally awake/active; empathetically connecting with others by working in a way that demonstrates creativity, values, beliefs, interpersonal relationships with others, thoughts, and feelings (Başoda, 2017). In short, job engagement is an individual's physical, cognitive, and emotional dedication as well as service to a professional role (Güler et al., 2019), and it is a desired professional quality in today's business world (Topaloğlu et al., 2019).

In our rapidly changing world, recognising the importance of commitment is a crucial issue for organisations (Krajcsák and Gyökér, 2013). Organisational commitment is an employee's psychological commitment to a workplace, and it can be defined as an employee's desire to stay within an organisation and strive for it, embracing the organisation's goals and values (Doğan and Kılıç, 2007). Meyer and Allen (1991) stated that organisational commitment has three components, namely, affective, continuance, and normative, and this approach was considered as a basis for other studies on organisational commitment (Doğan and K1lıç, 2007). Affective commitment is an employee identifying with the organisation and, as a result, exhibiting an extraordinary effort for the benefit of the organisation. Continuance commitment occurs when employees stay at the organisation because they believe they might lose the benefits they gained if they leave the organisation. Normative commitment occurs when employees continue to be members of the organisation as they believe their job at the organisation is right and honourable.

The concept of organisational justice, which affects the motivation and performance of the employees, sets forth that the principles on which the practices at the organisation are based should be clear, individuals should not be treated differently, and if individuals are treated differently, the reasons of this should be explained transparently (Koçel, 2014). In short, organisational justice is the role of justice in the workplace (Moorman, 1991). The three dimensions of organisational justice are distributive, procedural, and interactional justice (Korkut, 2019; Öngel and Şenol, 2019). Distributive justice is the perception of fairness of outcomes received by employees (Greenberg, 1990). Distributive justice is the distribution of reward/penalty, pay, status, and promotion etc. between the employees, and the perception that this distribution is made fairly by the employers. Procedural justice is about whether the process used in making decisions about the distribution of benefits is fair. Interactional justice is the dimension that depends on interactions such as respect to employee rights and equal treatment of all employees, which are adopted by decision makers in the process of implementation of decisions. Organisational justice has significant consequences, such as job satisfaction, organisational commitment, performance, and intention to resign (Çakar and Yildız, 2009; Kumar and Gupta, 2008). In other words, organisational justice affects the employee's commitment and trust toward the organisation. Therefore, it can be said that organisational justice has a moderator role in relation to attitudes, behaviours, and some outcome variables.

The social exchange theory, to which Blau (1964) gave its final form, is defined as a series of actions that create interdependent social responsibilities (Karagonlar et al., 2015). 
The reasons for maintaining mutual relations include a sense of success, desired stimulus, and an effort to maintain the pleasure acquired from the current situation (Lum, 2008). The award gained or the price paid by an individual due to the social relationship determines whether this relationship will continue. This applies to an individual working within an organisation. This means that the employee demonstrates a positive attitude and behaviour toward the employer due to the economic and social benefits provided by the employer (Rhoades et al., 2001). The opportunities that the organisation offers to the employees - such as improving professional competence in economic and social terms, including career development, promotions, and raises - would ensure that the employees demonstrate positive attitudes and behaviours toward the organisation. The idea that benevolence will not be unreciprocated will ensure the continuity of the relationship. This will ensure that the employee further adheres to the rules of the organisation, remains in the organisation, and has more passion toward the organisation and the work.

\subsection{Research hypotheses and model}

Organisational support means the organisation values the employees' support and increases their happiness (Özdevecioğlu, 2003). Therefore, career development can also be evaluated within the scope of organisational support. Dai and Qin (2016) identified a positive and significant relationship between perceived organisational support and job engagement. Bai and Lui (2018) identified a positive and significant relationship between career development and job engagement. Zhou et al. (2015) demonstrated that organisational commitment has a mediating role in the relationship between career development and job engagement. Weng et al. (2010) found a positive and significant relationship between career development and normative commitment. Buys and Rothmann (2010) and Simons and Buitendach (2013) reported a positive and significant relationship between organisational commitment and job engagement. If the employees trust that there is justice within the organisation, it will be easier for them to notice the organisation's support in terms of career development, thereby internalising behaviour codes, that is, normative commitment.

Based on the empirical studies investigating the relationship between career development and job engagement, the hypotheses developed to test the effect of career development on job engagement are listed below:
$H_{1}$ : Career development affects job engagement positively and significantly.

$\mathrm{H}_{2}$ : Career development affects normative commitment positively and significantly.

$H_{3}$ : There is a positive and significant relationship between normative commitment and job engagement.

$\mathrm{H}_{4}$ : Normative commitment has a mediating role in the relationship between career development and job engagement.

$H_{5}$ : When normative commitment has a mediating role between career development and job engagement, organisational justice has a moderator role between those two variables.

The research model established in relation to organisational justice, career development, job engagement, and normative commitment variables is shown in Fig. 1.

\section{Method}

The method section of the study includes the purpose of the research; the research universe, samples, and descriptive statistics; data collection techniques, limitations of the study, and the programs used in the study.

\subsection{The purpose of the study}

The purpose of the study is to investigate the relationships between career development (CD), job engagement (JE), normative commitment (NC), and organisational justice (OJ); and whether NC has a mediating role on CD's effect on JE, and whether OJ has a moderating effect in this relationship. In that context, the study sought answers to the following questions:

- Does CD have a significant effect on JE?

- Does CD have a significant effect on NC?

- Does NC have a significant effect on JE?

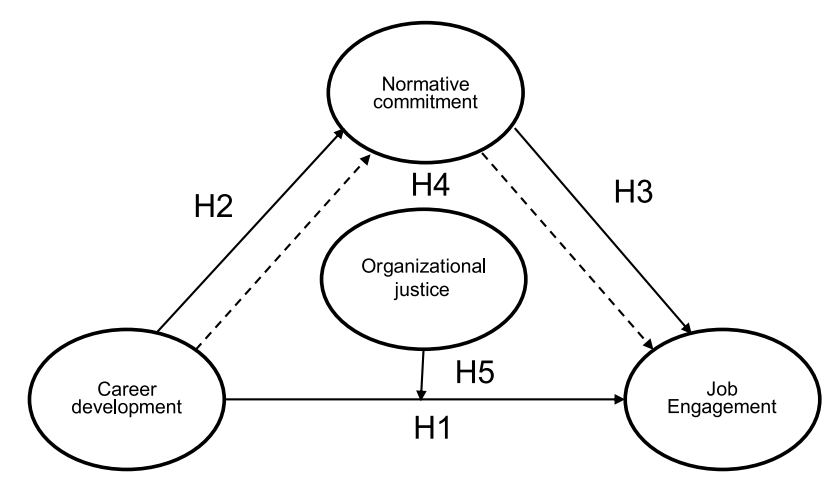

Fig. 1 Research model 
- Does $\mathrm{NC}$ have a mediating role in the relationship between $\mathrm{CD}$ and JE?

- When NC has a mediating role between $\mathrm{CD}$ and JE, does OJ have a moderator role on these two variables?

\subsection{Study universe, sampling, and descriptive statistics}

The study was conducted between July and October 2019 for academics from four foundation universities in the Ankara and Mersin provinces of Turkey and used four scales. It was established that a total of 354 people were working at the four foundation universities at the time of the survey. Therefore, this group formed the universe of the study. The sampling volume of the study was calculated by using a table in Sekaran (1992:p.253). The sample size that will represent the universe at $5 \%$ significance level with a $5 \%$ error margin was calculated as 185 . This calculated value is the minimum sample size targeted in relation to the sample volume in the study.

The survey used for creating the data set for the study included five sections: 1. Demographic Data, 2. Career Development Scale, 3. Job Engagement Scale, 4. Normative Commitment Scale, and 5. Organisational Justice Scale. This survey was conducted on the staff at four foundation universities through a web-based platform. Therefore, the data obtained are primary data. The survey link was sent to 274 academics via WhatsApp, and 234 academics completed the survey. Because this figure is higher than 185, which was calculated as the minimum number of samples, it was decided that the collected data is sufficient to conduct an analysis.

Of the respondents, 89 were female (37\%) and 145 were male (63\%); 113 had a bachelor's degree (46\%), 72 had a master's degree (27\%), and 49 had a doctorate degree (27\%); 36 were teaching fellows (18\%), 120 were research assistants (49\%), and 78 were teaching assistants (33\%); 113 were between the ages of 21 and $40(42 \%), 79$ were between the ages of 41 and $60(39 \%)$, and 42 were aged 60 or older $(19 \%)$.

\subsection{Data collection techniques}

In the study, a survey form comprising five sections was used as the data collection tool. The first section had 4 questions about the demographics of the respondents; the second section had 9 questions about CD (one sub-dimension); the third section had 6 questions about JE (three sub-dimensions and two questions in each sub-dimension); the fourth section had 6 questions on NC (one sub-dimension); the fifth section had 18 questions about
OJ (two sub-dimensions; 14 questions in the first sub-dimension, and 4 questions in the second sub-dimension); together, this amounted to a total of 43 questions. The considerations about the scales used in the study are explained in the following paragraphs.

Career Development Scale: It was originally developed by Simpson (2014) as a six-question scale and then adapted to Turkish by Kaya (2018). However, Kaya (2018) added three more questions to the scale and created a new scale more appropriate for Turkish culture. The scale comprises nine questions and is one-dimensional. The respondents were asked to answer the questions that were created based on a 5-point Likert scale (1. Strongly disagree, 2. Disagree, 3. Neither agree nor disagree, 4. Agree, and 5. Strongly agree). Kaya (2018) reported that the new scale's factor load values changed between 0.58 and 0.84 ; it can account for $51 \%$ of the variance; Cronbach's alpha coefficient is 0.861; and goodness of fit is $\chi^{2}: 12.645(p=0.555)$, GFI: 0.975, NFI: 0.95, CFI: 0.989, RMSEA: 0.001. In this study, only confirmatory factor analysis was performed on the CD Scale, and the goodness of fit values are presented in the relevant section following the information on the scales.

Job Engagement Scale: It was originally developed by Schaufeli et al. (2006). The scale has three subscales; namely, vigour, dedication, and absorption. The scale comprises a total of nine questions, three questions in each subscale. The scale was adapted to Turkish by adhering to the original by Eryılmaz and Doğan (2012) and Özkalp and Meydan (2015). Validity studies conducted by Schaufeli et al. (2006) in ten different countries on one-dimensional structure of the nine-question test demonstrated that Cronbach's alpha internal consistency coefficient varied from 0.85 to 0.92 . The three sub-dimensional scale's Cronbach's alpha reliability coefficient was 0.94 . In Turkey, Güler et al. (2019) simplified the scale by removing some questions in a way that would not disturb the scope of the scale, and then it was compared with the original. In this study, Güler et al. (2019) used the simplified version of the scale that had three subscales, each comprising two questions, which had a better goodness of fit value compared with others. In this context, the goodness of fit values of the scale were calculated as $\chi^{2}: 356.596, p(0.000)<0.01$, TLI: 0.949, CFI: 0.957, NFI: 0.921, RMSEA: 0.049; the Cronbach's alpha coefficient for the complete scale was 0.93 , for the vigour subscale was 0.93 , for the dedication subscale was 0.94 , and for the absorption subscale was 0.93. Although Schaufeli et al. (2006) used a 7-point 
Likert scale for the survey, Güler et al. (2019) used a 6-point Likert scale and chose the following options: "1. Almost never (a few times a year or less), 2. Rarely (once a month or less), 3. Sometimes (a few times a month or less), 4. Often (once a week), 5. Very often (a few times a week or less), and 6. Always (every day)." The scale used by Güler et al. (2019) was applied in this study, and only confirmatory factor analysis was performed on the JE Scale. The obtained goodness-of-fit values are presented in the relevant section following the information about the scales.

Normative Commitment Scale: The NC subscale of the three-dimensional Organisational Commitment Scale developed by Allen and Meyer (1990) was used in this study. The scale was adapted to Turkish by Kurşunoğlu et al. (2010). There are six questions in the NC subscale. Kurşunoğlu et al. (2010) opted for a 5-poin Likert scale instead of the 7-point Likert scale in the original (1. Strongly disagree, 2. Disagree, 3. Neither agree nor disagree, 4. Agree, and 5. Strongly agree). The decision to choose a 5-point Likert scale was affected by Meyer and Allen's (2004) comment that the scale in question can be changed, and that a 5-point scale also gives quite positive results. The value of the Cronbach alpha coefficient was determined as 0.744 in the study. In this study, only confirmatory factor analysis was performed on the NC Scale, and the goodness-of-fit values are presented in the relevant section following the information on the scales.

Organisational Justice Scale: The OJ Scale was originally created by Donovan et al. (1998), and it was adapted to Turkish by Wasti (2001). The scale comprises 18 questions and two subscales: relationship with supervisors and relationship with employees. The relationship-with-supervisors subscale comprises 14 questions, and the relationship-with-employees subscale has 4 questions. Seven questions in the relationship-with-supervisors subscale and 2 questions in the relationship with employees subscale were coded reversely. The participants were asked to use a 3-point Likert scale to answer the questions in this scale (1. No, 2. Indecisive, and 3. Yes). Wasti (2001) calculated the goodness-of-fit values as $\chi^{2}: 356.81, p(0.000)<0.01$, GFI: 0.84, AGFI: 0.88, NNFI: 0.92, and RMSEA: 0.072 in ensuring validity and reliability of the scale; the Cronbach alpha coefficient was reported as 0.93 for the whole scale, 0.93 for the relationship-with-supervisors subscale, and 0.81 for the relationship-with-employees subscale. In this study, only a confirmatory factor analysis was performed on the OJ Scale; the goodness-of-fit values are presented in the relevant section following the information on the scales.

\subsection{Limitations of the study}

The study is limited to Ankara and Mersin provinces, the scales used for collecting data in the study, the sample size in respect of the $\mathrm{NC}$ variable and moderator effect of OJ variables of the research, the programs used in the analyses, the statistical methods applied, and foundation universities.

\subsection{Programs used in the analyses in the study}

SPSS and AMOS package programs and $\mathrm{R}$ and Python programming languages were used in the analysis of data in this study. In this context, tests were conducted for uniand multi-variate distribution assumptions of the data used in the study; confirmative factor analyses were performed for scales via AMOS package programs; correlation analysis was performed via SPSS package program and Python programming language; and analyses were conducted for the mediating effect of $\mathrm{NC}$ variable and moderator effect of $\mathrm{OJ}$ variables.

\section{Findings}

3.1 Confirmatory factor analysis for the scales, and multivariate normality tests for the data used in the study

Confirmatory factor analysis of scales was performed before the analyses. The data needs to show a multivariate normal distribution before the confirmatory factor analysis can be performed. In this context, a Henze-Zirkler (HZ) test was conducted in $\mathrm{R}$ programming language to test whether the data showed a multivariate distribution, and then confirmatory factor analysis was performed via AMOS package program.

For the HZ test in R programming language, readxl and $M V N$ packages and readxl and $M V N$ libraries were used. The results calculated after the analysis were as follows: $H Z$ test value for JE Scale: 3.346339, p-value: 0.06, and MVN: YES; HZ test value for CD Scale: 5.711583, p-value: 0.12, and MVN: YES; HZ test value for NC Scale: 7.875949, p-value: 0.15, and MVN: YES; HZ test value for OJ Scale: 5.458077, p-value: 0.11 , and $M V N$ : YES. The results of the analysis indicate that the data used in the study shows a multivariate normal distribution ( $p$-value $>0.05$ and $M V N$ : YES).

After testing the multivariate normal distribution assumption of the data, confirmatory factor analysis was conducted on the AMOS package program. The confirmatory factor analysis showed that the JE Scale had three subscales, and the factor loadings were between 0.95 and 0.98 for vigour, between 0.93 and 0.95 for dedication, and between 0.90 and 0.96 for absorption; and the 
goodness-of-fit values were CMIN/DF: 2.429, RMSEA: 0.028, TLI: 0.981, and CFI: 0.993; the CD Scale had one subscale, the factor loadings were valued between 0.466 and 0.944, and goodness-of-fit values were CMIN/DF: 4.524, RMSEA: 0.026, TLI: 0.930, and CFI: 0.963; the NC Scale had one subscale, the factor loadings were valued between 0.466 and 0.944 , and goodness-of-fit values were CMIN/DF: 4.318, RMSEA: 0.022, TLI: 0.946, and CFI: 0.989; and the OJ Scale had one subscale, the factor loadings were valued between 0.466 and 0.944 , and goodness-of-fit values were CMIN/DF: 4.318, RMSEA: 0.022, TLI: 0.946, and CFI: 0.989. An investigation of the goodness-of-fit values for these four scales showed that OJ Scale's $\chi^{2} / \mathrm{sd}$ and TLI goodness of fit values were very close to the reference values in the literature $\left(\chi^{2} / \mathrm{sd}:<5\right.$, RMSEA: $<0.05, T L I:>0.90, C F I:>0.90)$; and the goodnessof-fit values of other scales were compatible with the reference values (Meydan and Şeşen, 2011). Therefore, it was decided that the scales could be used without any changes to the structures and questions.

\subsection{Investigation of the relationship between variables}

An Anderson-Darling Test was used in $\mathrm{R}$ programming language to determine whether there is a univariate normal distribution. The Nortest package and Nortest library were used for the test in the $\mathrm{R}$ programming language. The analysis results revealed a univariate normal distribution for the mean values of the scales: (JE: A test $=0.31256$ $p(0.6854)>0.05, \mathrm{CD}$ : A test $=0.29457 p(0.5821)>0.05$, NC: A test $=0.22563 p(0.5185)>0.05$, and OJ: A test $=$ $0.23144 p(0.5278)>0.05)$.

Causality requires a relationship between the variables. To investigate the relationship between the variables, a correlation analysis was conducted in Python programming language, hierarchical regression analyses were conducted in SPSS package program (first and second steps), and tests were conducted in $\mathrm{R}$ programming language regarding single variate normal distribution of the data. In all three analyses, the average values of responses obtained from scales were used as variable values.

The mean, standard deviation and correlation values of variables are presented in Table 1. Python programming language's pandas, numpy, and statsmodels packages and the necessary functions in these packages were used for the analyses.

The values in Table 1 were interpreted based on " 0.00 0.19: very weak, 0.20-0.39: weak, 0.40-0.59: medium, $0.60-0.79$ : strong, and 0.80-1.00: very strong" reference
Table 1 Means, standard deviations, and corelation coefficients of variables

\begin{tabular}{lcccccc}
\hline & Mean & s.d. & JE & CD & NC & OJ \\
JE & 3.91 & 1.330 & 1 & & & \\
CD & 3.57 & 0.865 & $0.402^{*}$ & 1 & & \\
NC & 3.64 & 0.719 & $0.417 *$ & $0.589 *$ & 1 & \\
OJ & 2.07 & 0.320 & $0.522^{*}$ & $0.342 *$ & $0.510 *$ & 1 \\
$*<0.05$ & & & & & &
\end{tabular}

relationship values (Evans, 1996). When the results of the analysis based on these reference values are examined for $p=0.01$ significance level:

- There was a significant and medium level same directional relationship between JE and JD;

- There was a significant and medium level same directional relationship between JE and NC;

- There was a significant and medium level same directional relationship between JE and OJ;

- There was a significant and medium level same directional relationship between $\mathrm{CD}$ and $\mathrm{NC}$;

- There was a significant and weak same directional relationship between $\mathrm{CD}$ and $\mathrm{OJ}$;

- There was a significant and medium level same directional relationship between NC and OJ. These findings show that the data is suitable for the hierarchical regression model.

\subsection{Investigation of the mediating effect of $\mathrm{NC}$ and moderator effect of $\mathrm{OJ}$ on $\mathrm{JE}$}

In this section, the mediating effect of $\mathrm{NC}$ and the moderator effect of OJ in the relationship between JE and CD have been examined with the Structural Equation Model in the AMOS package program. In the examination, firstly, the effect of CD on JE was analysed and subsequently, depending on the determined relationship between JE and CD, the mediating effect of $\mathrm{NC}$ and the moderator effect of OJ was investigated.

\subsubsection{Analysis of the relationship between JE and CD}

The effect of CD on JE was examined on the model established in the AMOS package program. The formal representation of the model established in this context is given in Fig. 2 and some parameters and goodness of fit values of the model are included in Table 2. In the model established, the mean values of the question items ( 9 items) in the $\mathrm{CD}$ variable, which has only one sub-dimension, and the question items in the sub-dimensions of the JE variable with three sub-dimensions (1st sub-dimension: 2 items, 


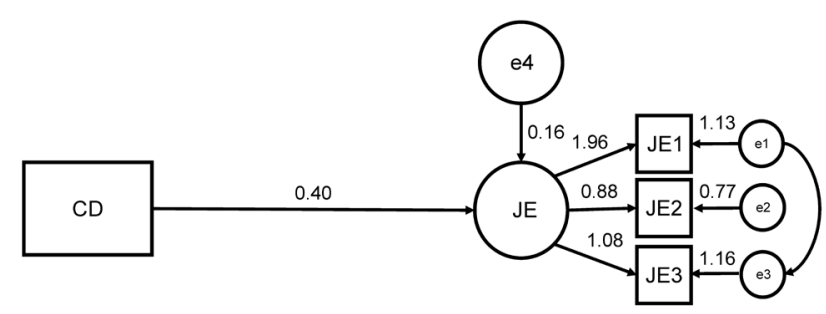

Fig. 2 CD's Effect on JE

2nd sub-dimension: 2 items, 3rd sub-dimension: 2 items) average values were used. Therefore, in the model established, CD variable is represented by rectangular (measurable variable) and JE variable is represented by circle (three sub-dimensional latent variables).

When the statistical values of the model established between the JE and CD variables in Table 2 are examined, the goodness-of-fit values of the model were in the range of reference values in the literature and the data fit "acceptable" to the established model, the path coefficient (standardised $\beta$ coefficient) was significant $(p<0.05)$ and, depending on this, CD affected JE. has been determined. As a result, the $H_{1}$ hypothesis of the obtained result is supported.

\subsubsection{Mediation effect of NC in the relationship between $\mathrm{JE}$ and $\mathrm{CD}$}

After examining the effect of $\mathrm{CD}$ on JE and finding a significant relationship between them, it was examined here whether NC has a mediating effect on this relationship.

In this context, the new model obtained by adding the $\mathrm{NC}$ variable to the model established with JE and CD in the AMOS package program is shown in Fig. 2, and the goodness-of-fit values and the path coefficient obtained related to the model are included in Table 3. In the new model, the average values of the question items (6 items) of the NC variable, which has a sub-dimension like other variables, were used. For this reason, the NC variable is represented by a rectangle (measurable variable) in Fig. 3.

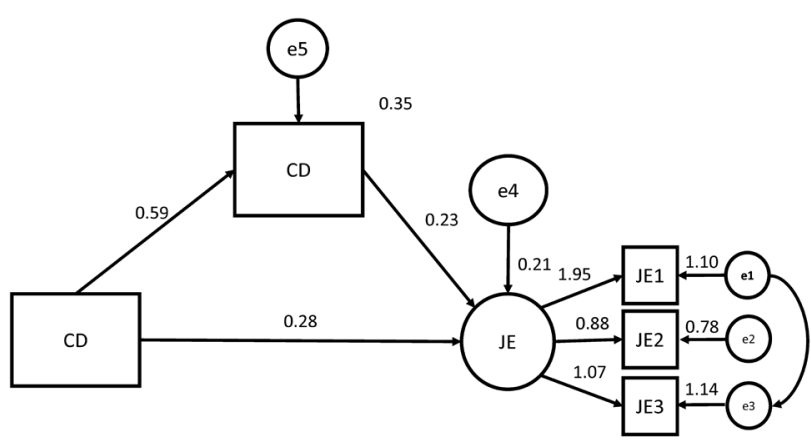

Fig. 3 Mediation effect of NC in the relationship between JE and CD

When the statistical values of the model established between JE, CD and NC in Table 3 are examined, the path coefficients between variables (standardised $\beta$ coefficients $(\mathrm{CD} \rightarrow \mathrm{JE}: 0.283, \mathrm{CD} \rightarrow \mathrm{NC}: 0.589$ and $\mathrm{NC} \rightarrow \mathrm{JE}: 0.232))$ are significant $(p<0.05)$, the goodness of fit values of the model are in the range of reference values in the literature, and it has been determined that the data are "acceptable" fit to the established model. When the path coefficients related to $\mathrm{CD} \rightarrow \mathrm{JE}$ in the models in Figs. 1 and 2 are compared within the scope of the mediation effect, both path coefficients are significant $p<0.05$ ), but the path coefficient in Fig. 1 decreases according to the path coefficient in Fig. 2. (Fig. 1: $\beta$ : 0.404 and Fig. 2: $\beta$ : 0.283). This situation shows that $\mathrm{NC}$ plays a partial mediating role in the relationship between JE and CD. To confirm this situation, a Sobel test was performed. The logic of the Sobel test is to test the significance of the change in the regression coefficient by taking into account the regression weights of the variables in the model and the standard errors of the relationships between the variables (Sobel, 1982). In this context, the statistical values obtained as a result of the Sobel test $(Z=2.154 ; p<0.05)$ confirmed that NC plays a partial mediating role in the relationship between JE and CD. Hence, $H_{1}, H_{2}$ and $H_{3}$ hypotheses are accepted.

Table 2 Path coefficient and goodness-of-fit values regarding the effect of CD on JE

\begin{tabular}{ccccccccc}
\hline & Standardized & s.e. & $p$ & RMSEA $^{*}<0.08$ & CFI* $^{*} 0.95$ & NFI* $>0.90$ & CMIN $/$ DF $^{*}<5$ & TLI* $>0.90$ \\
\hline $\mathrm{CD} \rightarrow \mathrm{JE}$ & 0.404 & 0.088 & 0.00 & 0.079 & 0.999 & 0.998 & 2.44 & 0.992 \\
\hline
\end{tabular}

* Goodness-of-fit values are arranged according to "acceptable" standards.

Table 3 Path coefficients and goodness of fit values related to NC's mediation effect in the relationship between JE and CD

\begin{tabular}{|c|c|c|c|c|c|c|c|c|}
\hline & Standardized & s.e. & $p$ & $\mathrm{RMSEA}^{*}<0.08$ & $\mathrm{CFI}^{*}>0.95$ & $\mathrm{NFI}^{*}>0.90$ & $\mathrm{CMIN} / \mathrm{DF}^{*}<5$ & $\mathrm{TLI}^{*}>0.90$ \\
\hline $\mathrm{CD} \rightarrow \mathrm{JE}$ & 0.283 & 0.083 & 0.00 & 0.048 & 0.999 & 0.996 & 1.505 & 0.996 \\
\hline $\mathrm{CD} \rightarrow \mathrm{NC}$ & 0.589 & 0.045 & 0.00 & & & & & \\
\hline $\mathrm{NC} \rightarrow \mathrm{JE}$ & 0.232 & 0.096 & 0.00 & & & & & \\
\hline
\end{tabular}

\footnotetext{
* Goodness-of-fit values are arranged according to "acceptable" standards.
} 


\subsubsection{Moderator effect of $\mathrm{OJ}$ on the relationship between $\mathrm{JE}$ and $\mathrm{CD}$}

In this section, after determining that $\mathrm{NC}$ has a partial mediating effect on the relationship between JE and CD in the model in Fig. 3, OJ has been added to the model, and it has been examined whether OJ has a moderator role in the relationship between JE and $\mathrm{CD}$. In this context, OJ and CD_OJ interaction variable (CD * OJ) has been added to the model in Fig. 3. Thus, the formal representation of the new research model created in the AMOS package program is shown in Fig. 4, and the path coefficients of the model and the goodness of fit values of the data are included in Table 4. In the new model, the mean values of the question items (1st sub-dimension: 14 items and 2nd sub-dimension: 4 items) of the sub-dimensions of the OJ variable, which has two sub-dimensions, and the multiplication values of the question items of the $\mathrm{CD}$ and $\mathrm{OJ}$ variables were used. For this reason, the OJ variable is represented with circle (two sub-dimension latent variable) and CD_OJ interaction variable with rectangle (measurable variable) in Fig. 4.

When the statistical values of the model established among the JE, CD, OJ and CD_OJ variables in Table 4 are examined, the path coefficients of $\mathrm{CD} \rightarrow \mathrm{JE}(\beta: 0.297)$ and $\mathrm{OJ} \rightarrow \mathrm{JE}(\beta:-0.331)$ are significant $(p<0.05)$ but the path coefficient of CD_OJ $\rightarrow \mathrm{JE}(\beta: 0.438)$ is insignificant $(p>0.05)$. Therefore, according to this result, it is con-

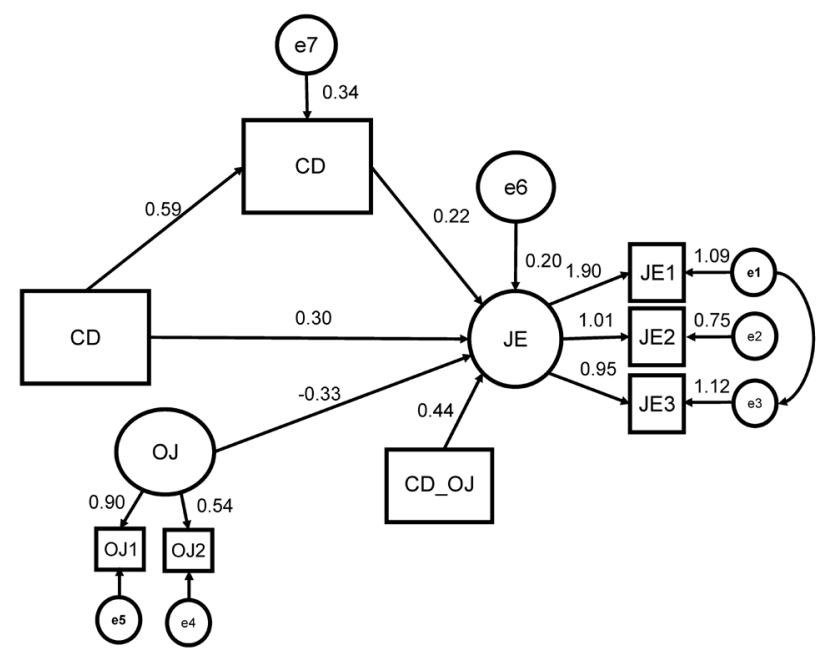

Fig. 4 Moderator effect of OJ on the relationship between JE and CD cluded that OJ does not have a moderator role in the relationship between CD and JE. In this context, the hypothesis is not acceptable.

\section{Conclusions and recommendations}

This study investigated the relationship between the concepts of $\mathrm{CD}, \mathrm{JE}, \mathrm{NC}$, and $\mathrm{OJ}$, and whether $\mathrm{NC}$ has a mediating role and OJ has a moderator role on CD's effect on JE. The study universe comprised the academic staff members from four foundation universities in Ankara and Mersin provinces, and data were collected using four different scales conducted on the academic staff.

The results demonstrated that $\mathrm{CD}$ has a positive and significant effect on JE and $\mathrm{NC}$; there is a positive and significant relationship between $\mathrm{NC}$ and JE; and $\mathrm{NC}$ has a partial mediating effect on the relationship between $\mathrm{CD}$ and JE. It was seen that $\mathrm{NC}$ plays a complete mediating role on the relationship between $\mathrm{CD}$ and JE, but OJ does not have a moderator role for these two variables.

Although having people directing their energy and attention to their work is a desirable behaviour, this is very hard to achieve today. It is now perfectly normal for people to have careers in multiple organisations until they retire. Career development is one of the instruments that organisations use as a motivational tool to increase people's commitment to the organisation and their JE. The award gained or the price paid by an individual is an important factor in determining whether an employee will remain a member of an organisation. Therefore, offering awards that would satisfy the need for respect and self-realisation would help people in devoting themselves to their jobs physically, mentally, and emotionally.

In contrast, people live for the values and principles that they believe to be true. These abstract concepts are of greater importance than material factors, including career, and they determine the way people live and behave. Employees may remain in an organisation and engage with their job because they may believe their job is right and ethical. In fact, this study demonstrated that CD affects JE through this type of commitment. Therefore, to achieve JE for employees, who are an important factor in reaching

Table 4 Path coefficients and goodness of fit values related to OJ's moderator effect in the relationship between JE and CD

\begin{tabular}{|c|c|c|c|c|c|c|c|c|}
\hline & Standardised $\beta$ & s.e. & $p$ & RMSEA $*<0.08$ & $\mathrm{CFI}^{*}>0.95$ & $\mathrm{NFI}^{*}>0.90$ & CMIN / DF* <5 & $\mathrm{TLI}^{*}>0.90$ \\
\hline $\mathrm{CD} \rightarrow \mathrm{JE}$ & 0.297 & 0.89 & 0.000 & & & & & \\
\hline $\mathrm{OJ} \rightarrow \mathrm{JE}$ & -0.331 & 0.78 & 0.000 & 0.074 & 0.97 & 0.975 & 2.587 & 0.981 \\
\hline $\mathrm{CD}$ & 0.438 & 0.71 & 0.089 & & & & & \\
\hline
\end{tabular}

* Goodness-of-fit values are arranged according to "acceptable" standards. 
organisational goals, the job should be right, ethical, and aligned with the values of the employee. The managers should create this environment and employ people whose values are in line with that of the organisation. Thus, aligning with the employee in terms of mission, vision, and values would contribute to creating this environment.

Justice is the basis of everything, especially trust. No actions or words are meaningful without justice. Justice can be defined as having clear principles for the practices within the organisation, not treating people differently, and providing transparent explanations for different treatments. Therefore, the expected results may be different depending on whether there is justice or not. The results of this study showed that NC plays a mediating role between $\mathrm{CD}$ and $\mathrm{JE}$, but OJ does not have a moderating role, which may be because the employees believe what they are doing is

\section{References}

Allen, N. J., Meyer, J. P. (1990) "The measurement and antecedents of affective, continuance and normative commitment to the organization", Journal of Occupational Psychology, 63(1), pp. 1-18. https://doi.org/10.1111/j.2044-8325.1990.tb00506.x

Bai, J., Liu, J. (2018) "A Study on the Influence of Career Growth on Work Engagement Among New Generation Employees", Open Journal of Business and Management, 6(2), pp. 300-317. https://doi.org/10.4236/ojbm.2018.62022

Başoda, A. (2017) "İşe tutkunluk: Kavramsal açıdan bir inceleme" (Work engagement: A conceptual review), Tarihin Peşinde, 17, pp. 71-98. (in Turkish)

Buys, C., Rothmann, S. (2010) "Burnout and engagement of reformed church ministers", SA Journal of Industrial Psychology, 36(1), pp. 825-836. https://doi.org/10.4102/sajip.v36i1.825

Büyükyaprak, F. (2015) "Çalışan kadın personelin kariyer gelişimi engellerinden cam tavan sendromu: Millı̂ Eğitim Bakanlığı Merkez Teşkilatı örneği" (A sample from Central Organization of Ministry of National Education; One of the obstacles of carreer development of working women glass ceiling syndrome), Yayımlanmamış Yüksek Lisans Tezi, Türk Hava Kurumu Üniversitesi Sosyal Bilimler Enstitüsü, Ankara, Turkey. (in Turkish)

Can, H. (1994) "Organizasyon ve Yönetim" (Organization and Management), Siyasal Kitabevi, Ankara, Turkey. (in Turkish)

Cummings, T., Worley C. G. (2009) "Organizational Development \& Change", South-Western Educational Publishing, Nashville, OH, USA.

Çakar, N. D., Yıldız, S. (2009) "Örgütsel adaletin iş tatmini üzerindeki etkisi: "Algılanan örgütsel destek" bir ara değişken mi?" (The effects of organizational justice on job satisfaction: Is "perceived organizational support" a mediator?), Elektronik Sosyal Bilimler Dergisi, 8(28), pp. 68-90. (in Turkish)

Dai, K., Qin, X. (2016) "Perceived Organizational Support and Employee Engagement: Based on the Research of Organizational Identification and Organizational Justice", Open Journal of Social Sciences, 4(12), pp. 46-57. https://doi.org/10.4236/jss.2016.412005 right and ethical. In fact, this study was conducted on academics, and members of this profession believe that their job contributes to society and is ethical. The scientists have a clear career path, and the respect they get from the society and their peers depends on the quality of their work. Therefore, the results may be different in other sectors.

This research also has some limitations. The most important limitation is that this study was conducted only on academicians. Different results may be obtained if the research is carried out in different sectors. Another limitation of the study is its longitudinal character. The fact that the study was conducted on a limited number of foundation universities within a specific geography may also be considered as a limitation. Future studies may investigate other organisational practices that may affect JE and other dimensions of organisational commitment other than the NC.

Donovan, M. A., Drasgow, F., Munson, L. J. (1998) "The Perceptions of Fair Interpersonal Treatment Scale: Development and validation of a measure of interpersonal treatment in the workplace", Journal of Applied Psychology, 83(5), pp. 683-692. https://doi.org/10.1037/0021-9010.83.5.683

Doğan, S., Kılıç, S. (2007) "Örgütsel bağlılı̆̆ın sağlanmasında personel güçlendirmenin yeri ve önemi" (The situation and importance of empowerment in obtaining organizational commitment), Erciyes Üniversitesi İktisadi ve İdari Bilimler Fakültesi Dergisi, 29, pp. 37-61. (in Turkish)

Eryılmaz, A., Doğan, T. (2012) "İş Yaşamında Öznel Iyi Oluş: Utrecht Işe Bağlılık Ölçeğinin Psikometrik Niteliklerinin Incelenmesi" (Subjective Well-Being at Work: Investigating of Psychometric Properties of Utrecht Work Engagement Scale), Klinik Psikiyatri, 15(1), pp. 49-55. (in Turkish)

Evans, J. D. (1996) "Straightforward Statistics for the Behavioral Sciences", Brooks/Cole Publishing, Pacific Grove, CA, USA.

Greenberg, J. (1990) "Organizational Justice: Yesterday, Today and Tomorrow", Journal of Management, 16(2), pp. 399-432. https://doi.org/10.1177/014920639001600208

Güler, M., Çetin, F., Basım, H. N. (2019) "İşe Tutulma Ölçeği Çok Kısa Versiyonu (UWES-3) Geçerlik ve Güvenirlik Çalışması: Alternatif Bir Versiyon (UWES-6) Önerisi" (Validity and reliability study of hiring scale very short version (UWES-3): An alternative version (UWES-6) proposal), İş ve İnsan Dergisi, 6(2), pp. 189-197. (in Turkish) https://doi.org/10.18394/iid.516921

Hitka, M., Lorincová, S., Ližbetinová, L., Schmidtová, J. (2017) "Motivation Preferences of Hungarian and Slovak Employees Are Significantly Different", Periodica Polytechnica Social and Management Sciences, 25(2), pp. 117-126.

https://doi.org/10.3311/PPso.10052

Karagonlar, G., Öztürk, E. B.,Özmen, Ö.N. T.(2015)"Çalışanınörgütle sosyal mübadele algısı ve işten ayrılma niyeti: İşe cezbolmanın ve öz yeterliliğin rolü" (Employee's perception of social exchange with the organization and intention to quit: The role of attractiveness and selfefficacy), ODTÜ Gelişme Dergisi, 42(3), pp. 411-433. (in Turkish) 
Kaya, A. (2018) "Kariyer Gelişim Sürecinin Örgütsel Bağl1lık ve Işten Ayrılma Niyeti Üzerine Etkisinin Yapısal Eşitlik Modellemesi ile Test Edilmesi" (Testing the Effect of Career Development Process on Organizational Commitment and Intention to Leave with Structural Equation Modeling), PhD Thesis, Hitit Üniversitesi, Sosyal Bilimler Enstitüsü. Available at: http://cdn. hitit.edu.tr/sbe/files/90808_180508094728.pdf [Accessed: 11 August 2021] [in Turkish]

Kılıç, G., Öztürk, Y. (2010) "Kariyer yönetim sistemi ve örgütsel bağl1lık arasındaki ilişki: Beş yıldızlı otel işletmelerinde bir araştırma" (The relation between career management system and organizational commitment: A research in five-star establishments), Ege Akademik Bakış, 10(3), pp. 981-1011. (in Turkish) https://doi.org/10.21121/eab.2010319625

Koçel, T. (2014) "İşletme Yöneticiliği" (Business Management), Beta, İstanbul, Turkey. (in Turkish)

Korkut, A. (2019) "Öğretmenlerin örgütsel mutluluk, örgütsel sinizm ve örgütsel adalet algılarının analizi" (An analysis of teachers' perceptions of organizational happiness, organizational cynicism and organizational justice), PhD, İnönü Üniversitesi Eğitim Bilimleri Enstitüsü. (in Turkish)

Krajcsák, Z., Gyökér, I. (2013) "How to increase workplace commitment?", Periodica Polytechnica Social and Management Sciences, 21(1), pp. 39-44. https://doi.org/10.3311/PPso.2155

Kumar, K., Gupta, G. (2008) "Perceived Organizational Justice, Job Satisfaction and Turnover Intentions: A Co-Relational Study", Gujarat Journal of Psychology, 25-26, pp. 1-8.

Kurşunoğlu, A., Bakay, E., Tanriöğen, A. (2010) "İlköğretim Okulu Öğretmenlerinin Örgütsel Bağlılık Düzeyleri" (Organizational Commitment Levels of Elementary School Teachers), Pamukkale Üniversitesi Eğitim Fakültesi Dergisi, 28, pp. 101-115. (in Turkish)

Lu, J. H., Chen, L. L., Zhan, X. N. (2013) "Relationship study on perceived organizational support, organizational commitment support and engagement of knowledge employees", Science and Science Technology Management of S. \& T., 34(1), pp. 147-153.

Lum, T. (2008) "Social Exchange Theory: The Maker and Breaker of Relationship", Nā Mana'o, 1(1), pp. 1-7.

Meydan, C. H., Şeşen, H. (2011) "Yapısal Eşitlik Modellemesi (AMOS Uygulamaları)" (Structural Equation Modeling (AMOS Applications)), Detay Yayıncılık, Ankara, Turkey. (in Turkish)

Meyer, J. P., Allen, N. J. (1991) "A three-component conceptualization of organizational commitment", Human Resources Management Review, 1(1), pp. 61-89.

https://doi.org/10.1016/1053-4822(91)90011-Z

Meyer, J. P., Allen, N. J. (2004) "TCM Employee Commitment Survey: Academic Users Guide 2004", Western University, London, ON, Canada.

Moorman, R. H. (1991) "Relationship between organizational justice and organizational citizenship behavior: Do fairness perceptions influence employee citizenship?", Journal of Applied Psychology, 76(6), pp. 845-855.

https://doi.org/10.1037/0021-9010.76.6.845
Öngel, V., Şenol, Ş. (2019) "İçsel pazarlama uygulamalarının çalışanların iş tatmini üzerine etkisi ve örgütsel adaletin aracılık rolü" (The effect of internal marketing practices on employees' job satisfaction and the mediating role of organizational justice), Akademik Hassasiyetler, 6(12), pp. 445-475.(in Turkish)

Özdevecioğlu, M. (2003) "Algılanan örgütsel destek ile örgütsel bağl1lık arasındaki ilişkilerin belirlenmesine yönelik bir araştırma" (A research to determine the relationships between perceived organizational support and organizational commitment), Dokuz Eylül Üniversitesi İktisadi İdari Bilimler Fakültesi Dergisi, 18(2), pp. 113-130. (in Turkish)

Özkalp, E., Meydan, B. (2015) "Schaufeli ve Bakker tarafından geliştirilmiş olan işe angaje olma ölçeğinin Türkçe'de güvenirlik ve geçerliğinin analizi" (Analysis of the reliability and validity of the engagement scale developed in Turkey by Schaufeli and Bakker in Turkish), İş, Güç Endüstri İliş̧ileri ve İnsan Kaynakları Dergisi, 17(3), pp. 4-19. (in Turkish) https://doi.org/10.4026/1303-2860.2015.0285.x

Rasouli, R., Rashidi, M., Hamidi, M. (2014) "A Model for the Relationship Between Work Attitudes and Beliefs of Knowledge Workers with Their Turnover Intention", Periodica Polytechnica Social and Management Sciences, 22(2), pp. 149-155. https://doi.org/10.3311/PPso.7626

Rhoades, L., Eisenberger, R., Armeli, S. (2001) "Affective commitment to the organization: The contribution of perceived organizational support", Journal of Applied Psychology, 86(5), pp. 825-836. https://doi.org/10.1037/0021-9010.86.5.825

Schaufeli, W. B., Bakker, A. B., Salanova, M. (2006) "The Measurement of Work Engagement With a Short Questionnaire: A CrossNational Study", Educational and Psychological Measurement, 66(4), pp. 701-716.

https://doi.org/10.1177/0013164405282471

Sekaran, U. (1992) "Research Methods for Business: A Skill-Building Approach", John Wiley \& Sons, New York, NY, USA

Simons, J. C., Buitendach, J. H. (2013) "Psychological capital, work engagement and organisational commitment amongst call centre employees in South Africa", SA Journal of Industrial Psychology, 39(2), Article number: a1071. https://doi.org/10.4102/sajip.v39i2.1071

Simpson, M. J. (2014) "The Relationship Between Provision of Career Development Services and Employee Turnover", PhD Thesis, Northern Illinois University.

Sobel, M. E. (1982) "Asymptotic Confidence Intervals for Indirect Effects in Structural Equation Models." Sociological Methodology, 13, pp. 290-312.

https://doi.org/10.2307/270723

Topaloğlu, E. Ö., Sönmez, R., Yazgan, A. E. (2019) "Çalışmaya Tutkunluk ve Iş Yaşam Dengesi Arasındaki Ilişki: Banka Çalışanları Üzerine" (Relationship Between Passion for Work and Work-Life Balance: On Bank Employees), BDDK Bankacılık ve Finansal Piyasalar Dergisi, 13(1), pp. 66-83. (in Turkish)

Wasti, S. A. (2001) "Örgütsel adalet kavramı ve tercüme bir ölçeğin Türkçe'de güvenirlik ve geçerlik analizi" (The concept of organizational justice and reliability and validity analysis of a translated scale in Turkish), Yönetim Araştırmaları Dergisi, 1, pp. 33-50. (in Turkish) 
Weng, Q., McElroy, J. C., Morrow, P. C., Liu, R. (2010) "The relationship between career growth and organizational commitment", Journal of Vocational Behavior, 77(3), pp. 391-400. https://doi.org/10.1016/j.jvb.2010.05.003

Weng, Q. X., Xi, Y. M. (2011) "The Relationship between Dynamic Professional Environment for Career Growth and Organizational Commitment", Management Science, 14, pp. 48-59.
Zhou, X., Yu, J. M., Cao, G. L. (2015) "The Relationship between Career Growth and Employee Engagement: Based on the Mediating Effect of Organizational Commitment", Soft Science, 10, pp. 88-91. 